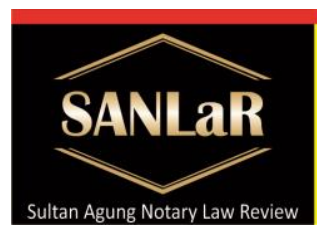

\title{
Comparison of Advanced Children According to West Law, Compilation of Islamic Law, and Traditional Law of Bugis Customs
}

\author{
Anriani $^{*}$ \\ *) Students of Master of Notary Law, Faculty of Law, Universitas Islam Sultan \\ Agung (UNISSULA) Semarang, E-mail: anriani702@gmail.com
}

\begin{abstract}
The objectives of this study are as follows: 1) To determine the comparison to what extent the position of adopted children in inheriting the assets of their adoptive parents according to Western law, compilation of Islamic law and customary law of the Bugis tribe in Wolo District, Kolaka Regency. 2) To find out what are the obstacles in the application of inheritance distribution according to Western Law, Compilation of Islamic Law and Customary Law of the Bugis Tribe in Wolo District, Kolaka Regency. Based on the data analysis, it can be concluded that: 1) Comparing the extent to which the position of adopted children in inheriting the assets of their adoptive parents according to Western law, the Compilation of Islamic Law and Customary Law of the Bugis Tribe in Wolo District, Kolaka Regency is as follows: In Islamic law, adoption does not have legal consequences in terms of blood relations, guardian-guardianship and inheritance relationships with adoptive parents. He remains the heir of his biological parents and the child continues to use the name of his biological father.Meanwhile, according to the West Inheritance Law are: In Staatblaad 1917 No. 129, the legal consequence of adoption is that the child legally acquires the name of the adoptive father, becomes the child born from the marriage of the adoptive parents and becomes the heir of the adoptive parents. That is, as a result of the appointment, all civil relations are cut off, which originates from the offspring due to birth, namely between the biological parents and the child.Meanwhile, according to the Customary Law of the Bugis tribe, they are as follows: When using customary institutions, the determination of inheritance for adopted children depends on the applicable customary law. Especially the Bugis tribal law that If the adopted child is obtained from his/her own family environment, it will result in an unbroken relationship between the child and the biological parents in family relations and assets. And if the adopted child is adopted from the environment outside the family, it can result in the relationship between the adopted child and the biological parents being cut off, especially in relation to assets or inheritance. 2) What are the obstacles in the application of inheritance distribution according to Western Law, Compilation of Islamic Law and Customary Law of the Bugis Tribe in Wolo District, Kolaka Regency, namely: because of the lack of legal education for the community in the process of legalizing adopted children, Lack of public understanding and awareness in the process of distributing inheritance.
\end{abstract}

Keywords: Empirical Juridical Review; Adopted Children; Bugis Culture. 


\section{Introduction}

The desire to have children for each husband and wife is a human instinct and by nature these children are a mandate of Allah SWT to the husband and wife. For parents, the child is expected to be able to raise the degree and dignity of the parents, when they become adults. The facts show that many marriages which are painstakingly built eventually dissolve because of household problems caused by not having children. As a social being, the family is the smallest community group, which consists of a father, mother, and child. However, these three elements are not always fulfilled, so sometimes there is a family that does not have children, for this reason the couple adopts a child.

In Indonesia, adoption has been known since the Majapahit era. In the Kutara Manawa book (the book of religious legislation) there is the word "adopted child from another person" which indicates that at that time the adoption agency was already known. ${ }^{1}$ Nowadays adoption generally has several goals or motivations. Among other things, to continue the offspring if in a marriage they do not have children. ${ }^{2}$

This motivation is very strong for married couples who are unlikely to bear children. In addition, the purpose of adoption can only be done in the best interests of the child and it is carried out based on custom local and the provisions of the applicable laws and regulations. ${ }^{3}$

This provision greatly guarantees protection for children whose nature is very dependent on their parents. There are several reasons for married couples to adopt children, among others, the reluctance to have children after passing the safe age limit for childbirth, the lack of desire to conceive and give birth and their ability to no longer allow to bear a child, so that one way to have children can be done by raising the child. The emergence of such perceptions is based on the notion of adoption or adoption which states that "adoption is an act of taking someone else's child to be cared for and treated as his own descendant based on the agreed provisions and valid according to the applicable law in the community concerned." Natural disasters such as earthquakes followed by tsunamis, volcanic eruptions, flash floods and so on, where as a result of the disaster many children have lost their parents so that some married couples in good faith care for and educate the children of victims of the disaster. Juridically, this can be done based on the applicable legal provisions. However, sociologically and cultural values also affect a child adopted by adoptive parents who are not of the same nationality and belief. banjir bandang and the like, where the consequences of the disaster left many children who lost their parents so that

\footnotetext{
${ }^{1}$ Rusli Pandika. (2011). Hukum Pengangkatan Anak. Jakarta: Sinar Grafika. p. 2.

${ }^{2}$ Republic of Indonesia, Act No. 23 Year 2002 regarding Child Protection Article 39 paragraph 1.

${ }^{3}$ Ibid. Article 39 paragraph 2
} 
several married couples in good faith to care for and educate the children of the victims of the disaster. Juridically, this can be done based on the applicable legal provisions. However, sociologically and cultural values also affect a child adopted by adoptive parents who are not of the same nationality and belief. banjir bandang and the like, where the consequences of the disaster left many children who lost their parents so that several married couples in good faith to care for and educate the children of the victims of the disaster. Juridically, this can be done based on the applicable legal provisions. However, sociologically and cultural values also affect a child adopted by adoptive parents who are not of the same nationality and belief.

The practice of adopting children with commercial motives, trafficking, just for inducement and after obtaining their own children, then wasted adoption is very contrary to the inherent rights of the child. Therefore, adoption must be based on a strong spirit to provide assistance and protection so that the future of the adopted child will be even better.

The important thing that must be realized for prospective adoptive parents and biological parents, is that the prospective adoptive parents must have the same religion as the religion adopted by the prospective adopted child because the influence of religion of the adoptive parents on the adopted child only has one direction from the adoptive parents with the child adoption and if it is not in line, it will seriously hurt the conscience and creed of the adopted child's parents. ${ }^{4}$ In addition, there are also adoptions of children that are merely of magical value, such as children who are sick, by their parents being handed over by someone else by "selling" the child, both to their own relatives and to others.

This action is expected so that the child does not get sick anymore. Here the child is not surrendered in the real or real sense, the child remains in the original family, likewise there is no obligation between the adopted child and the adoptive parents, but only the child's call to the adoptive parent as is the call to the original parent. Adoption of children like this is common, especially in West Java, Central Java and East Java, but this action is not a legal action so it has no juridical value. Adoption of a child is a natural thing to do in accordance with the circumstances experienced by the adoptive parents so that what becomes a concern in adopting this child is the granting of the right to live for a child.

The existence of adoption institutions in Indonesia, in this case, is that legal institutions for adoption are deemed inadequate so that the resolution of adoption problems in society can be viewed from various legal aspects. As customary law which is the living law applies to local indigenous communities, Islamic law derived from the Al-Qur'an and Hadith also regulates this issue for

${ }^{4}$ Fauzan. (1999). Pengangkatan Anak Bagi Keluarga Muslim Wewenang Absolute Peradilan Agama, Majalah Mimbar Hukum, December 1999, No.10. p. 56 
the Muslim community, western legal provisions derived from BW Civil Law (Burgerlijk Wetboek) also apply in Indonesia. ${ }^{5}$

Regarding adoption according to Civil Law, it refers to the provisions of Stb. 1917 No. 129. In the provisions of Article 12 Stb. 1917 No. 129, with adoption, then the adopted or adopted children use the surnames of the adoptive parents and have the same legal position as the biological children of the adoptive parents and have the same legal position as the biological children of the adoptive parents. With such appointment, the adopted child has the same position as the heir of the $a b$ intestine. So that an adopted child should have the right to inherit from his adoptive parents just like a biological child born in a legal marriage. Such adoption is an act that equates the position of adopted children with biological children be it in terms of maintenance and down to inheritance. As has been explained also in Articles 11, 12, 13 and 14 of Stb. 1917 No. 129. There are two kinds of methods of obtaining an inheritance according to civil law, namely as an heir according to law or ab intestine and because he is appointed in a testament. By looking at the provisions of Stb. 1917 No. 129, then the adopted child has the same position as the heirs of the ab intestine to acquire an inheritance according to civil law. According to Stb. 1917 No. 129, adopted children will break their lineage to their biological parents, and there will be a lineage relationship with their adoptive parents, so that the adopted child will also become the heir of the adoptive parents. However, this Staatsblad provides another limitation of the right to inherit an adopted child, which is that the adopted child only becomes the heir of an inherited portion. The provisions of Civil Law BW of the adoption of a legal child result in a legal relationship between the adoptive parents and the adopted child, namely a family relationship that is the same as that between the parents and the biological child, including using the name of the adoptive parent and entering as a child into the marriage of the adoptive parent. So an adopted child has the right to inherit the inheritance of his adoptive parents according to the legitieme portie of all forms of inheritance and as the absolute heir of his adoptive parents as regulated in Article 852 of the Civil Code.

In Islamic law, adoption does not carry legal consequences in blood relations and does not become the basis and cause of inheritance, because the basic principle and cause of inheritance is to have blood relations. ${ }^{6} \mathrm{He}$ remains the heir of his biological parents and continues to use the name of his biological father. Regarding adoption (tabanni), it is only a form of dedication to Allah regarding the existence of the gift of Allah who has given so many gifts. So that the adoption of the child is not meant to be an heir.

When Islam came, which gave an explanation of the number of male and female heirs and the causes of damage, then the adopted child's right to inherit only was

\footnotetext{
${ }^{5}$ Azhar Basyir. (1986). Hukum Adat Bagi Ummat Islam. Yogyakarta: UII Press. p. 10

${ }^{6}$ Soedharyo Soimin. (2002). Hukum Orang dan Keluarga, Edisi Revisi. Jakarta: Sinar Grafika. p. 38
} 
based on heredity, because not inheriting was only based on the offspring. Meanwhile, the element of adoption cannot force it to be the cause of the nasab assessment. In other words, the incidence of adoption according to Islamic kawarisan law does not have a legal effect on the status of the adopted child, that is, if he is not a child himself, he cannot inherit from the person who after adopting the child. This, of course, will cause problems in the future if the inheritance is not understood by the adopted child, because according to Islamic law,

As stipulated in the Compilation of Islamic Law Article 209 verse 2 which reads: "To an adopted child who does not receive a will, a will is given as much as $1 / 3$ of the inheritance of his adoptive parents". The issue of adoption and distribution of inheritance according to the Islamic Law Compilation above is interesting for the author to discuss. According to the general provisions in the Compilation of Islamic Law, Article 171, an adopted child is a child who, in terms of maintaining for his daily life, the cost of education and so on, shifts the responsibility from the original parent to the adoptive parent based on a court decision. ${ }^{7}$ On the basis of this understanding, it is clear that what is prohibited according to Islamic law is the adoption of children as biological children in all respects.

From this, it can be seen that there is a point of intersection according to the provisions of civil law, which eliminates or decides the position of the adopted child with his own biological parents. This is a principle in the Adoption institution because there are provisions that eliminate the rights of the biological father and can overhaul the provisions regarding inheritance.

Based on the description above, it is appropriate if there is a way to bridge the problems of adopted children, so that the adopted children can be cared for properly and their future can be guaranteed, especially with regard to the inheritance of the adopted child.

One of the crucial issues that will be raised in this study is the issue of adoption for Muslim communities in Indonesia, where most of them think that with the adoption of the child, the status of the adopted child will change from his biological parents to become compassionate to his adoptive parents the inheritance system was transferred to the adoptive parents. Whereas Islam prohibits adoption of children who break blood ties with their biological parents, let alone to obtain inheritance from their adoptive parents.

\section{Research methods}

This study uses an empirical juridical approach, so the appropriate data collection techniques for this study include library research and field research. The data used are sourced from primary data and secondary data. Primary data

${ }^{7}$ Article 171 Presidential Instruction No. 1 of 1991 concerning Compilation of Islamic Law 
(main) is the researcher himself obtained from a list of questions, field notes and through directional interviews. Meanwhile, secondary data (supporting) is a compilation of Islamic law and literature from books, scientific texts, research reports, mass media, and others. Field data collection will be carried out by means of interviews, namely structured interviews. Structured interviews were conducted with guidelines on the list of questions provided by the researcher. The material is expected to develop in accordance with the informants' answers and the situation that develops.

\section{Results and Discussion}

3.1. Comparison of the extent to which the position of adopted children in inheriting the assets of their adoptive parents according to Western law, compilation of Islamic law and Bugis customs in Wolo District, Kolaka Regency According to the Customary Law of the Bugis Customs

Adoption of children in the indigenous Bugis tribe is carried out in two ways, namely: adoption of children obtained from their own environment, so it can be done simply by notifying the Customary Chair, RT, or Head of Kelurahan and adoption of children who are obtained from outside the family environment, then a traditional ceremony is carried out or with a thanksgiving ceremony officially.

Based on the adoption of the child above, it will create a certain legal relationship between the adopted child on the one hand and the biological parents on the other.

From the results of an interview with Mursidin, S.Ag, Wolo District who said the following: By adopting a child, it results in the emergence of a certain legal relationship between the adopted child and biological parents or adoptive parents with the following conditions:

1. If the adopted child is obtained from his own environment, it will result in an unbroken relationship between the child and the biological parents in family relations and assets.

2. And if the adopted child is adopted from the environment outside the family, it can result in the relationship between the adopted child and the biological parents breaking up, especially in terms of wealth or inheritance. ${ }^{8}$

The opinion of Mursidin, S. Ag above is in line with Rusdi's opinion, the secretary of Wolo Village stated as follows: Considering that most people are Muslim, the method of adoption and legal relations with adoptive parents and biological parents is influenced by Islamic teachings. As:

${ }^{8}$ Mursidin, S. Ag, Sekcam in Iwoimendaa District, interview on October 12, 2020 
1. If the adopted child comes from his own family environment, it will result in an unbroken legal relationship between the adopted child and his biological parents.

2. But if a child comes from a family environment or a relative of the parents who adopted him, especially the child he adopted comes from a different religion with his adoptive parents, then the child after being adopted will enter into Islam, then the legal relationship with the parents is direct. the biological parent is cut off, but if fellow Muslims then the relationship with the biological parents is not cut off, what is disconnected is only the supervision and control of the biological parent over the adopted child, while the control and obligations are now transferred to the parent who raises such as the need to provide for the living and the necessities education and so on. ${ }^{9}$ So here, in the case of the legal relationship between the biological parents and the adopted child or who is under the control of the parent who adopted him, some are disconnected if the adopted child comes from an outside environment of the adoptive parent's relative, but if the adopted child is still from the environment of the relatives of the parents who adopted him, the biological parent's relationship was not broken.

As for the property of the adoptive parents, namely $\mathrm{Hj}$. Dg. Tasannah, which was obtained by herself during the divorce from her husband in 2009 are as follows:

1. A house located in Wolo Village, Wolo District, Kolaka Regency.

2. Two Car Units

3. Two Motor Units

4. Meybel's business, both selling cabinets, Sprimbad, chairs, etc.

5. Clove farm located in Lasiroku Village, Iwoimendaa District

The assets obtained were given to an adopted son named Jumriani Iskandar, a son of the heir's younger brother. The heir has lived together since he was born into the world. However, since the child was in elementary school, then Pewaris adopted the child as his adopted child. It is proven by the recognition of the local community and the heir's family card has entered the heir as adopted children.

The reason for asking the biological child of the heir's brother to be made an adopted child is because the heir does not have children during marriage, and because the child has lived with the heir since he was a baby. Then the adopted son was 21 years old, he was married off to a man named Agusman.

At the age of 70 years, the heir is old enough and no longer healthy, so since then the heir asks his adopted son to take care of all the assets, especially in the business of the heir to hand over to his adopted son to continue his business. Then over time, the heir asks the adopted son so that the heir's name is behind

\footnotetext{
${ }^{9}$ Rudi, secretary of wolo village, interviewed on October 12, 2020
} 
the name of the heir, namely Jumriani Iskandar, and the adopted child gives trust to one of the PPAT Notaries in Kolaka so that all the assets owned by the heir are turned over to be behind the name according to the request. Inheritance in 2019.

\section{a. According to Islamic Law}

Inheritance law is often known as faraidh. This is because in Islam, the parts of the inheritance that are the right of the heirs have been determined in the Qur'an. Inheritance law in Islam has received great attention, because the distribution of inheritance often has unfavorable consequences. ${ }^{10}$

The law of inheritance according to fiqh mawaris is fiqh related to the distribution of inheritance, knowing the calculation in order to find out the portion of the inheritance and the parts that must be received from the inheritance for every person entitled to receive it. ${ }^{11}$

In Arabic, the transfer of something from one person to another or from one people to another is called Al-miirats. ${ }^{12}$ Meanwhile, the meaning of Al-miirats according to the terms known to the scholars is the transfer of ownership rights from the deceased to the surviving heirs, whether those left behind are in the form of property (money), land or anything in the form of legal property rights according to shari'i. The definition of inheritance law according to Article 171 letter a Compilation of Islamic Law is a law that regulates the transfer of ownership rights to the inheritance (tirkah) of the inheritance, determines who has the right to become heirs and how many parts of each. In a more general context, inheritance can be defined as the transfer of material rights from the deceased to the surviving heirs. Inheriting means taking the place of a person who dies in a legal relationship with his wealth. Other legal relations. In other editors, the law of inheritance is the law that regulates who is the person who inherits and does not inherit, the acceptance of each heir and the methods of distribution. ${ }^{13}$

The basis for the implementation of the distribution of inheritance in Islamic law is guided by the verses of the Qur'an which means: For men there is a right to share the inheritance of the mother-father and relatives, and for women there is a right to share (also) of the assets inheritance from mother-father and relatives, either a little or a lot according to the portion that has been determined (Surah Nisa; 7) This means: Allah makes a provision for you about (the distribution of

\footnotetext{
${ }^{10}$ Ahmad Rofiq. (1995). Hukum Islam di Indonesia. Jakarta: PT Raja GrafindoPersada. p.355

11 http://edon79.wordpress.com/2009/07/10/fiqh-mawaris/, accessed on November 2, 2020 at 10.30 WITA

${ }^{12}$ Muhammad Ali Ash-Shabuni. (1995). Pembagian Waris Menurut Islam. Jakarta: Gema Insani Press. p. 33

${ }^{13}$ Ahmad Rofiq. Op.cit. p. 355
} 
inheritance for) your children. Namely: the share of a boy is the same as that of two of his daughters; and if the children are more than two women, then to them two-thirds of the property that is left behind; if the girl is alone, then she will get half the wealth. and for two mothers and fathers, for each one sixth of the property left behind, if the deceased had children; if a person who dies does not have children and he is inherited by his/her parents (only), then the mother gets a third; if the deceased has several brothers, then the mother gets one sixth.

(The distribution mentioned above) after fulfilling the will that he made or (and) after being paid the debt. (Regarding) your parents and your children, you do not know which of them is closer (much) benefits you these are decrees from Allah. Allah is All-knowing, Most Wise.

\section{b. According to Western Law}

Adoption is a business that creates conditions that protect children from exercising their rights and obligations. Adoption of children is a manifestation of justice in a society. Thus, adoption must be endeavored in various fields of state and social life.

Inheritance Law is a law that regulates the transfer of assets left by a person who dies and the consequences for his heirs. ${ }^{14} \mathrm{As}$ a result of adoption according to the provisions in Stbl 1917 No. 129 whereas adoption of children for Indonesian citizens of Chinese descent causes the position of adopted children to be equated with biological children by the adoptive parents, so that adopted children have the right to inherit the assets of their adoptive parents. Regarding the adoption of this child, the Civil Code does not recognize him. In connection with this, Indonesian citizens of Chinese descent who are generally subject to the Civil Code have a separate regulation in Stbl 1917 No. 129, chapter II on adoption. According to Article 12 of this regulation, adopted children are equated with biological children and regarding inheritance the legal relationship between the parents and the child is terminated. Furthermore Article 14 says:

Due to adoption of children, civil rights are lost related to the lineage between biological parents and blood relatives and from the line to the side of the adopted person. In connection with these matters, adopted children of the Indonesian Citizenship of Chinese descent have the right to inherit property from the parents who adopted them, and in this case the system and inheritance rights regulated in the Civil Code apply to adopted children. The Civil Code that is still valid in Indonesia is based on the provisions of Article I of the Transitional

${ }^{14}$ Effendi Parangin. (2005). Hukum Waris. Jakarta: PT. Raja Grafindo Persada. p.3. 
Rules of the 1945 Constitution, which states that "all existing laws and regulations are still valid as long as a new one has not been made according to this Basic Law".

With the adoption of the child, in principle, all kinship with the family of origin is abolished (Article 14 Stbl 1917 No. 129) and now kinship with the family of the adoptive parents has arisen, which at first may have been nothing (Article 12 Stbl 1917 No. 129). The most obvious legal effect is the legal effect in inheritance law. Adopted children are no longer inherited from their original blood family, on the contrary, they now inherit from the family of the father and mother who adopted them. ${ }^{15}$ Those who are subject to the Civil Code, especially regarding the law of inheritance, are Indonesian citizens of Chinese descent. In this regard, the inheritance rights of adopted children adhere to the inheritance law system regulated in the Civil Code, except in certain cases (such as choice of law). As a comparison, the existing inheritance law system in our country apart from what is regulated in the Civil Code, there is also an Islamic inheritance law system and an inheritance law system.

3.2. What are the Obstacles in the Application of Inheritance Distribution according to Western Law, Compilation of Islamic Law, and Customary Law of the Bugis Tribe in Wolo District, Kolaka Regency

Family is the most important factor in life, where the family is a place where its members interact with each other around the daily environment, and it can be seen that in a family there is a component of children who have an important role to be the successor of the family or can be said to be heirs and successors assets that become inheritance of their parents after their parents die. In order for the inheritance to be preserved and can be used properly without causing a dispute for the future successor, the distribution must be in accordance with the applicable law.

Based on the facts that exist in society and in everyday life, there are often disputes, problems and obstacles that arise when the distribution of inheritance is carried out. The definition of dispute according to Duene Ruth-Hefelbower is a condition that occurs when two or more parties perceive that there are differences in positions that are not aligned, insufficient sources and actions of one party obstruct, or interfere or in some cases make the other party's goals less successful. Settlement of disputes regarding inheritance can be done by means of Islamic inheritance law, western inheritance law and customary inheritance law. Even considering the sensitivity of this area of inheritance law, to safeguard future disputes, In the distribution of inheritance for the Bugis ethnic community in Wolo District, problems often arise in the distribution of inheritance, including:

1. Injustice in the portion of the inheritance.

15 J. Satrio. (2005). Hukum Keluarga Tentang Kedudukan Anak Dalam Undang-Undang. Bandung: PT. Citra Aditya Bakti. p. 244 
Disputes in the family often occur because family members do not respect each other's family inheritance traditions (de'na Sipakatau). ${ }^{16}$ There is a sense of injustice to the choice of law chosen in completing the distribution of their inheritance, so that the distribution of inheritance is not in accordance with the expectations between relatives in the family.

2. The equal position of the heirs in receiving the distribution of inheritance.

Disputes between siblings in one family often occur because members of one family feel they have the same position in the family (at-pada mappunnai). So that there is a debate between brothers in one family, because they do not get a balanced distribution of inheritance, which results in disputes between siblings. His own desire to get a lot of assets against the inheritance, while the distribution of other relatives was neglected.

Inheritance disputes often occur some time after the heir dies. Disputes over inheritance do not only occur in parental communities but also in patrineal and matrineal communities. Because the members of indigenous peoples are more affected by their anger, arbitrary actions, greediness or greediness, as a result of the progress of the times and the emergence of many necessities of life so that shame, feelings of kinship and help have subsided.

In inheritance disputes, the object is in the form of property, which in the distribution of which often arises dissatisfaction for some heirs as well as ignorance of the parts that have been arranged as well as greed and selfishness. In practice, not all living legal values are considered to be accepted as material for consideration, but on the contrary, these values are corrected on the basis of consideration of a sense of justice.

For example, in inheritance disputes there is (grandchildren do not inherit from their grandmother, because their father died earlier than their grandmother). Since 1990 the public's understanding of this has been corrected with legal values that are considered more fulfilling a sense of justice, namely by applying the law of successor heirs.

There is also a public understanding that wives who (for example, wives leave the house) do not get a share of the joint property in the event of a divorce. This understanding is gradually corrected through a court decision by giving a share to the proven wife, as well as people who have so far doubted the position of a child whose mother was born out of wedlock, in several court decisions it has been confirmed that such a child is a legal child as long as it is born in the first place. or the result of a legal marriage.

What is common in the traditions of some Bugis communities is that women get more than their male relatives as those who inherit the goods obtained by Women are of greater value (for example houses, shop houses, gold) while brothers only get a smaller share, causing injustice then it is also a form of tyranny in inheritance.

3. There is a sense or desire to own and control the inheritance.

\footnotetext{
${ }^{16}$ Interview with Iswar Danianto, SH, Head of Wolo Village on December 5, 2020
} 
There is a sense or desire to control and even own inheritance because humans are never separated from the feeling and nature of the desire to have excessively, especially if it is related to the issue of inheritance in the form of houses or other inherited assets. One of the emergence of a sense of and desire to control and even own inherited property is a lack of sufficient sense of what you already have, besides that it could also be due to unhealthy economic problems in family life. The inheritance should be the property owned by the parents, so that every child is not entitled to control and even own the inheritance unilaterally, because, in the inheritance there are also other heirs' rights to obtain a share of the inheritance.

Especially in the practice of distributing inheritance to adopted children, based on findings in the field, it was found that the reasons that hampered the distribution of inheritance in Wolo District were due to several reasons, as follows:

a. Lack of community legal education in the process of legalizing adopted children.

The facts found in the field are that adopted children who have been appointed as heirs, are not limited to one family or one community, but most importantly how to ensure that the child has a good and prosperous future in the future, legalization of adoption is obligatory according to The law by registering it in court so that adoption has been carried out based on Bugis customary law can be recognized and legally valid so that the position of the child with the adoptive parents is strong because the State has recognized and protected the rights and obligations of the child with the adoptive parents. This needs to be done considering that if one day the child will have a legal relationship with the wider community so it is feared that problems will arise in the future.

b. Lack of understanding and public awareness of the inheritance distribution process according to Islamic law.

Based on the data obtained, almost $100 \%$ of the people of Wolo District are Muslims. However, only $2 \%$ share the inheritance according to Islamic law. The implementation of Islamic inheritance law itself must be through sufficient knowledge of religion, law and experience to be able to influence as well as provide information for people who do not or do not know the ins and outs of Islamic inheritance teachings. It's just that it needs to be considered so that there is no misunderstanding between those who know and those who do not know the Islamic inheritance law itself. This is done by several parties who understand it, but the obstacle encountered is the attachment of the community in general to the customs and habits that have long prevailed in the community.

The implementation of Islamic inheritance law is understandable in principle. Some of the Muslim community in Wolo District knows that in Islamic teachings there are laws that regulate inheritance issues but do not enforce that Islamic legal teachings must be carried out. Even the largest group of the Islamic community in Wolo district knows the existence of Islamic law itself as a living 
law to be realized. But not running as it should. So basically public awareness is determined by several factors, the existence of community disobedience, then there are some who do not fully accept the existence of Islamic law as a law that they must obey, some of them are ready to carry out teachings that come from the values of the Qur'an and the Hadith of the Prophet Muhammad.

c. The distribution of inheritance is only done orally (there is no document as authentic evidence).

Verbal distribution of inheritance is often carried out in society. This is because in the process of handing over an inheritance from the heir to the heir, it is carried out only on the basis of mutual trust and guarantees that no one will control. However, this is very prone to problems. If the heir has died and there are more than one heir, it is likely that the assets promised by the heir will be controlled by other heirs. Because, previously the heir only gave the inheritance only verbally and there were never any witnesses. The weakness of the distribution of inheritance which is carried out only orally lies in proving that the heir actually has given part of the inheritance to the heirs. This is due to the absence of authentic evidence or witnesses.

d. The lack of understanding and the high cost of managing the inheritance distribution deed made by a Notary.

The deed of inheritance distribution drawn up by or in front of a notary is as legal evidence that an inheritance has changed hands. However, there is a lack of understanding and the assumption that the cost of making an inheritance distribution deed made by a Notary is very expensive by the public, because when compared to the usual distribution of inheritance, almost no other costs need to be incurred. Even though the deed is needed as legal evidence. It is necessary to know this in the legacy process of inheritance deeds before a notary public in the following ways:

1) The Parties (Inheritors and Inheritors) Come to the Notary Public. The parties can come directly to the notary office with a deed of inheritance distribution according to legal provisions. The deed of inheritance distribution can be in the form of an underhand deed that has been signed by the parties and has been validated by the village head or sub-district head. The deed serves as provisional evidence, besides that, it is also required to carry other evidence related to the certificate of ownership of the inheritance to be divided. If the inheritance is in the form of land, proof of ownership can be in the form of a land certificate. As well as other proof of identity such as family cards (KK) and identity cards (KTP).

2) Requesting a Certificate of Inheritance (SKW). Inheritance Certificate (SKW) is a certificate which contains an explanation or information regarding the parties who are entitled to become legal heirs in the eyes of the law.

3) The Parties Express their Desires and Expectations. Wills can be conveyed orally or in writing to a notary. The aim is to give a share of the inheritance to each of the heirs that have been listed in the Certificate of Inheritance (SKW). At this 
stage, the active role of a notary is required. This means that at this stage the notary is neutral and does not side with any heirs.

4) Inheritance Deed Ready for Issuance. After the Parties have agreed on the distribution of the predetermined inheritance, the notary will finalize the agreement into the inheritance deed.

The procedure for making an inheritance deed made before a notary is indeed very different and tends to be more complicated. The procedure through a notary is much more than the usual customary procedure. Therefore, people prefer to share inheritance orally. This is also due to the fact that some of the people who argue that in order to administer and make an inheritance deed at a notary, the public or the parties have to pay a fee which tends to be very expensive, which is above IDR 1,500,000.00. On the other hand, to carry out the distribution of inheritance orally does not require and incur costs or funds.

e. Lack of the role of the government and related parties in providing legal education to the community

To realize the awareness of all Islamic societies about the distribution of inheritance according to Islamic law, it is necessary to hold more intensive counseling. This is where the role of the government through educational institutions in collaboration with the Ministry of Religion and Notary offices is needed to take action on counseling. The method used can be through direct and indirect counseling. Direct legal counseling is an extension program that does not use media, which can meet in person, such as providing legal counseling, lectures, discussion and so on. And indirect counseling uses printed media, leaflets and others. For the people of Wolo District, the most effective way is through direct counseling,

\section{Closing}

\subsection{Conclusion}

1. Comparing the extent to which the position of adopted children in inheriting the assets of their adoptive parents according to Western law, the Compilation of Islamic Law and Customary Law of the Bugis Tribe in Wolo District, Kolaka Regency is as follows: In Islamic law, adoption does not have legal consequences in terms of blood relations, guardian-guardianship and inheritance relationships with adoptive parents. He remains the heir of his biological parents and the child continues to use the name of his biological father. Meanwhile, according to the West Inheritance Law are: In Staatblaad 1917 No. 129, the legal consequence of adoption is that the child legally acquires the name of the adoptive father, becomes the child born from the marriage of the adoptive parents and becomes the heir of the adoptive parents. That is, as a result of the appointment, all civil relations are cut off, which originates in the offspring due to birth, namely between the biological parents and the child.Meanwhile, according to customary law are as follows:When using customary institutions, the determination of 
inheritance for adopted children depends on the applicable customary law. Especially the Bugis customary law thatlf the adopted child is obtained from his/her own family environment, it will result in the child's relationship with the biological parents being unbroken in kinship and wealth. And if the adopted child is adopted from the environment outside the family, it can result in the relationship between the adopted child and the biological parents breaking up, especially in terms of wealth or inheritance.

2. What are the obstacles in the application of inheritance distribution according to Western law, the compilation of Islamic law and customary law of the Bugis tribe in Wolo sub-district, Kolaka district, are as follows: that the lack of community legal education in the process of legalizing adopted children, Lack of public understanding and awareness of the process of distributing inheritance according to law Islam, distribution of inheritance is only carried out by oral means (documents as authentic evidence do not exist), Ununderstanding and expensive handling of inheritance deed made by Notaries, Lack of role of government and related parties in providing legal education to the community, Injustice in the portion of inheritance ;

\subsection{Suggestion}

1. Adoptive parents are expected to legalize adoption according to the law by registering it in court so that the adoption of the child based on Bugis customary law can be recognized and legally legal so that the position of the child with the adoptive parents is strong because the State has recognized and protected it, the rights and obligations of the child with the adoptive parents. This needs to be done considering that if one day the child will have a legal relationship with the wider community so it is feared that problems will arise in the future.

2. It is better if the role of the government or related parties is to provide legal counseling for the community regarding adopted children in inheriting, so that the community can understand and be able to adopt children according to the rules.

\section{References}

Books:

[1] Ahmad Rofiq. (2002). Fiqh Mawaris. Jakarta: PT Raja GrafindoPersada. p. 355

[2] Ahmad Rofiq. (1995). Hukum Islam di Indonesia. Jakarta: PT Raja GrafindoPersada. p.355

[3] Azhar Basyir. (1986). Hukum Adat Bagi Ummat Islam. Yogyakarta: UII Press. p. 10

[4] Soedharyo Soimin. (2002). Hukum Orang dan Keluarga, Edisi Revisi. Jakarta: Sinar Grafika. p. 38 
[5] Effendi Parangin. (2005). Hukum Waris. Jakarta: PT. Raja Grafindo Persada. p.3.

[6] Fauzan. (1999). Pengangkatan Anak Bagi Keluarga Muslim Wewenang Absolute Peradilan Agama, Majalah Mimbar Hukum, December 1999, No.10. p. 56

[7] J. Satrio. (2005). Hukum Keluarga Tentang Kedudukan Anak Dalam Undang-Undang. Bandung: PT. Citra Aditya Bakti. p. 244

[8] Muhammad Ali Ash-Shabuni. (1995). Pembagian Waris Menurut Islam. Jakarta: Gema Insani Press. p. 33

[9] Rusli Pandika. (2011). Hukum Pengangkatan Anak. Jakarta: Sinar Grafika. p. 2

\section{Regulations:}

[1] Republic of Indonesia, Act No. 23 of 2002 regarding Child Protection Article 39 paragraph 1

[2] Article 171 Presidential Instruction No. 1 of 1991 concerning Compilation of Islamic Law

Internet:

http://edon79.wordpress.com/2009/07/10/fiqh-mawaris/, accessed on November 2, 2020 at 10.30 WITA

Interview:

Interview with Iswar Danianto, SH, Head of Wolo Village on December 5, 2020 